\title{
NEW WHITE-LIPPED PECCARY (TAYASSU PECARI) RECORDS FOR THE COAST OF CAMPECHE, MEXICO
}

\author{
Mircea G. Hidalgo-Mihartt,3, Fernando M. Contreras-Moreno ${ }^{1}$, \\ Luz A. Pérez-Solano ${ }^{2}$, and Alejandro Jesús de la Cruz ${ }^{1}$
}

\begin{abstract}
Using camera traps, we recorded presence of the white-lipped peccary (Tayassu pecari; WLP) in the Chenkan region, an area of wetlands, mangroves, and tropical flood forest located on the coast of Campeche in Mexico. The WLP had been considered extinct in the area, so its rediscovery in Chenkan increases the known range of the current distribution of this species, which is classified as endangered in Mexico. The presence of WLP in Chenkan highlights the importance of the area for the conservation of this endangered species. Therefore, it is necessary to take effective conservation actions to maintain the region's natural ecosystems, which are under strong pressure from expanding agriculture and tourism infrastructure.
\end{abstract}

Resumen.-Registramos por medio de cámaras trampa la presencia de pecarí de labios blancos (Tayassu pecari; PLB) en la región de Chenkan, un área de humedales, manglares y bosques tropicales inundables localizada en la costa de Campeche, México. El PLB había sido considerado como extinto en el área, por lo que el redescrubrimiento de la especie en Chenkan extiende el área conocida de distribución actual de esta especie considerada en peligro de extinción en México. La presencia de PLB en Chenkan documenta la importancia del área para la conservación de especies en peligro. Por esta razón es necesario tomar acciones efectivas de conservación que permitan el mantenimiento de los ecosistemas naturales de la región, actualmente fuertemente presionados por la ampliación de la frontera agropecuaria y de infraestructura turística.

The white-lipped peccary (Tayassu pecari; WLP) and the collared peccary (Pecari tajacu) are species of the Tayassuidae family that are found in Mexico. Larger and heavier than the collared peccary $(>30 \mathrm{~kg})$, the WLP is characterized by its dark brown to jet black color and white hairs on the edges of the mouth, which give the animal its name. The WLP is also more associated with the hot and humid climates of the tropical wet forests than is the collared peccary. WLPs live in large groups that usually range from 30 to 50 individuals, although they occasionally form groups of more than 300 individuals (Sowls 1997). The historical distribution of the WLP extends through the wet tropical forests and subhumid Neotropical forests of Mexico to northern Argentina (Sowls 1997, Altrichter et al. 2012). In Mexico, the original distribution ranged from Veracruz and Oaxaca to the south and southeastern parts of the country, including the entire Yucatan Peninsula (Hall 1981), where the WLP inhabited tropical evergreen forests, semideciduous forests, and occasionally thorny tropical forests (March 2005). Populations have decreased dramatically throughout the range, mainly because of excessive hunting and deforestation. The International Union for Conservation of Nature (IUCN) has listed the WLP as vulnerable (Keuroghlian et al. 2013), given that this species has undergone a considerable decrease in the number and size of its populations throughout its distribution (Altrichter et al. 2012).

Due to hunting and habitat loss, the range of the WLP in Mexico has decreased by $84 \%$ (Altrichter et al. 2012). Thus, the species has recently been listed as endangered under Mexican law (Norma Oficial Mexicana NOM-059SEMARNAT-2010). The current distribution for this species in Mexico includes only the Chimalapas region in the state of Oaxaca, the Lacandona Rainforest in the state of Chiapas, and the southern Yucatan Peninsula (March 2005, Reyna-Hurtado et al. 2009, Altrichter et al. 2012). Additionally, a small population has recently been rediscovered in wetlands of western Campeche (Hidalgo-Mihart and ContrerasMoreno 2012), a relatively unexplored area where the species was thought to be extinct.

\footnotetext{
${ }^{1}$ División Académica de Ciencias Biológicas, Universidad Juárez Autónoma de Tabasco, C.P. 86040, Villahermosa, Tabasco, México.

${ }^{2}$ División de Posgrado, Instituto de Ecología A. C. Carretera Antigua a Coatepec 351. El Haya, 91070 Xalapa, Veracruz, México.

${ }^{3}$ E-mail: mhidalgo@yahoo.com
} 


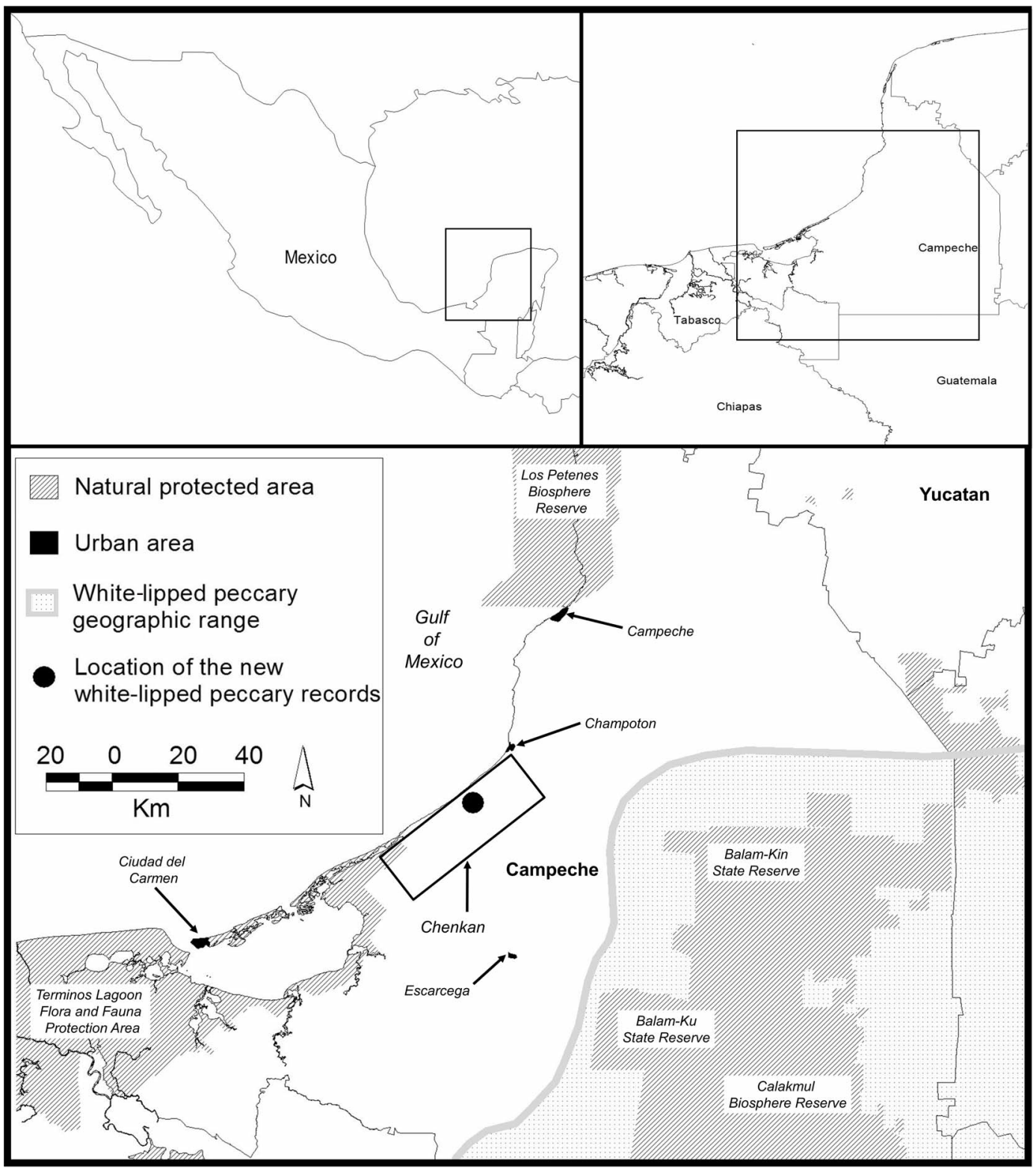

Fig. 1. Location of the Chenkan region in the state of Campeche, Mexico, indicating the site where white-lipped peccaries (Tayassu pecari) were recorded and the current geographic range of the species (Keuroghlian 2013).

As part of a study aimed at identifying areas that are important for conservation of the jaguar (Panthera onca) and its prey in coastal and wetland regions of western Campeche, Mexico, we set up camera traps in 2011 and 2012 throughout the region known as Chenkan (Fig. 1). With these cameras, we obtained photographs of WLPs on 3 occasions. These records are important because the WLP was thought to be extinct in the region (March 2005, Altrichter et al. 2012, Keuroghlian et al. 2013).

The study area is situated $15 \mathrm{~km}$ west of the city of Champotón, approximately $4 \mathrm{~km}$ from the coast of the Gulf of Mexico, and within 3 ejidos (Mexican communal lands under the stewardship of rural inhabitants and used for agriculture): San Pablo Pixtún, 

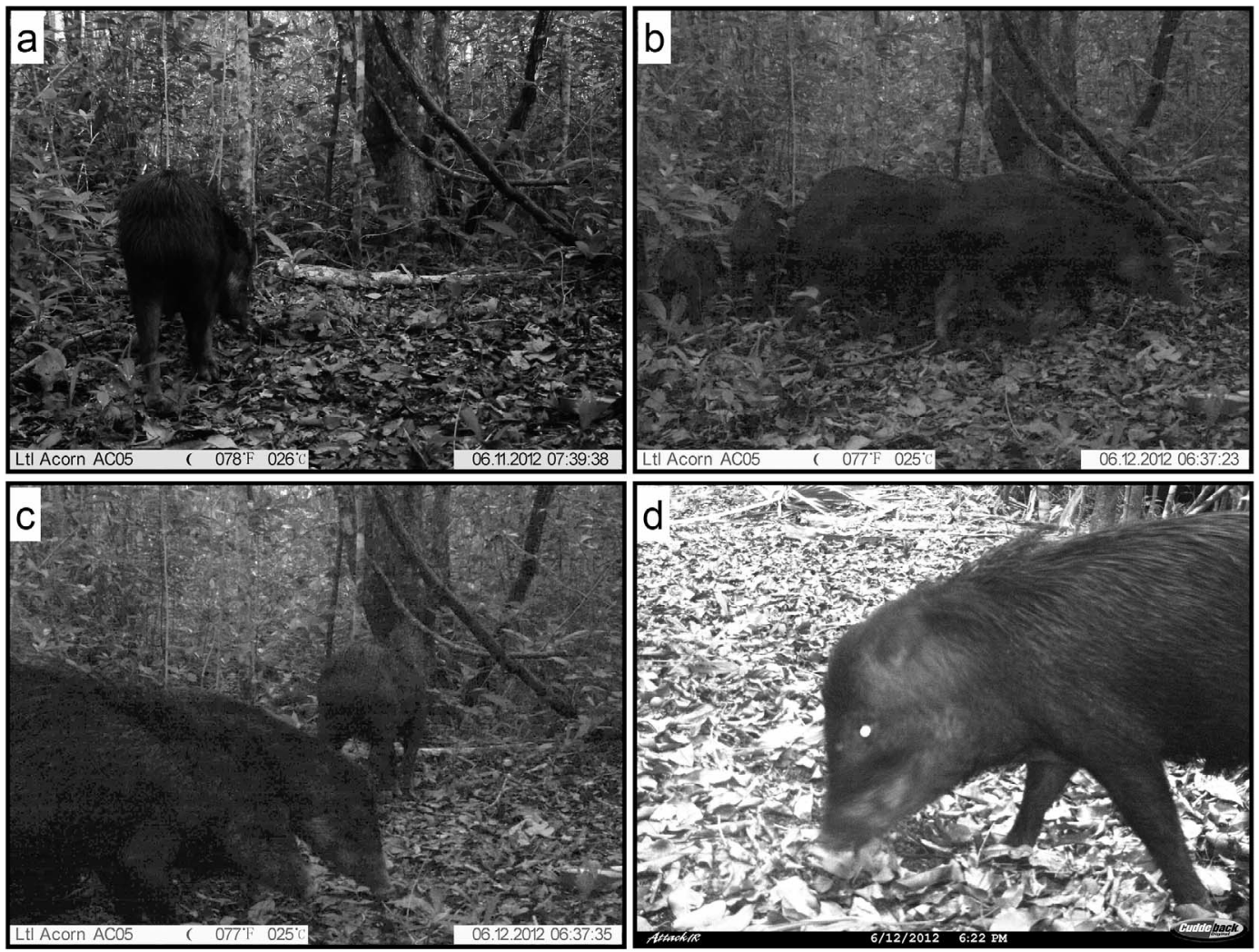

Fig. 2. Photographs of white-lipped peccaries (Tayassu pecari) obtained in the Chenkan region in 2012: a, whitelipped peccary; b, 5 white-lipped peccaries, including 2 offspring; c, 3 white-lipped peccaries; $\mathbf{d}$, white-lipped peccary. In panels $\mathrm{b}$ and $\mathrm{c}$, the contrast of the photographs was altered to improve image quality.

Ley Federal de la Reforma Agraria, and Punta Xen (Fig. 1). The region is flat, with an elevation of $0-5 \mathrm{~m}$ asl. According to López-Mendoza (1995), the vegetation of the region comprises systems associated with wetlands, such as mangroves, deciduous pukté (Bucida buceras) forest, low spiny logwood (Haematoxylon campechianum) forest, and calabash (Crescentia cujete) savannah. On the coast there are extensive areas covered by mangroves, mainly red mangrove (Rhizophora mangle). The deciduous pukté forest grows to a height of $20-30 \mathrm{~m}$ in deep soils, and logwood forest to a height of $5-15 \mathrm{~m}$. The savannah is composed of grasses, with either no trees at all or with isolated trees, mainly calabash, that grow no taller than $5 \mathrm{~m}$. All of these systems grow on poorly drained soils that become swampy during the rainy season and dry out completely during the dry season. Because the savannahs have various species of natural and introduced grasses (mainly jaragua, Hypharrenia rufa, and Mexican crowngrass, Paspalum fasciculatum), they are used during the dry season to pasture cattle. In the calabash savannah, there are patches of button mangrove (Conocarpus erectus) and, where the soil rises $1 \mathrm{~m}$ above the savannah, small patches $(<5 \mathrm{ha})$ of seasonal evergreen forest known as petenes. Though these natural systems still exist, cattle ranching has transformed some of the natural habitats into induced pastures where African star grass (Cynodon nlemfuensis) and German grass (Echinochloa polystachya) are dominant. In this area, there are also large expanses of secondary vegetation derived from the original forest systems, and these expanses are at different stages of succession (1-20 years old), which indicates constant use of the forested regions and plot abandonment. In this system, trees are generally $<5 \mathrm{~m}$ tall and have a diameter $<3 \mathrm{~cm}$. In Chenkan, only the beach is 
currently listed as a protected area (RAMSAR 1348 MEX-035 28 Feb 2004). The region forms part of the Priority Land Region (Región Terrestre Prioritaria, RTP-144 Pantanos de Centla; Arriaga et al. 2000) and is considered an important area for the conservation of mangroves (Región PY-75 Sabancuy-Chenkan; Comisión Nacional para el Conocimiento y Uso de la Biodiversidad 2009).

We obtained WLP records using camera traps that were originally set to determine the abundance of jaguar (Panthera onca) and its potential prey in Chenkan. To this end, we set 14 Cuddeback Attack IR (Non Typical, Inc., De Pere, WI) and 6 LTL Acorn 5210 A (OldBoys Outdoors, Stone Mountain, GA) digital camera traps from June to August in 2011 and 2012. We set the traps along pathways, firebreaks, and roads. We tied the cameras to trees at a height of $50 \mathrm{~cm}$ and programmed them to function $24 \mathrm{~h}$ per day. To increase the visitation rate of carnivores to the camera sites, we baited the sites with canned sardines. Cameras were separated by at least $1 \mathrm{~km}$.

We did not obtain any records of the WLP during 2011. In the 2012 survey, we obtained the first 2 WLP records from a camera trap located on a firebreak dirt road inside an area of deciduous pukté forest (UTM 15N 726103, 2118954). The first record was obtained with 2 photographs of an adult WLP (sex unknown) taken on 11 June 2012 at 07:39 (Fig. 2a). The second record was obtained on 12 June 2012 with 11 photographs taken between 06:36 and 06:39 (Fig. 2b, 2c). There are 4 photographs with a single WPL, 3 with 2 individuals, 2 with 3 individuals, and 2 with 5 individuals. Only one of the photographs shows 2 offspring (Fig. 2c). In the other photographs, only adults are observed. A third record was obtained on 12 June 2012 from a camera that was set up on a firebreak dirt road in an area of deciduous pukté forest surrounded by red mangrove (UTM $15 \mathrm{~N} 728722,2121580)$. In this record, there are 5 photographs of WLPs taken between 18:22 and 18:24 (Fig. 2D). There is a single photograph with one WLP, 2 with 2 individuals, and 2 with 4 individuals. All of these photographs are of adult WLPs of indeterminate sex. The distance between the 2 cameras was $3.7 \mathrm{~km}$.

The WLP was considered extinct in Chenkan (Keuroghlian et al. 2013). However, the photographs that we obtained show that this species still inhabits the area. The closest confirmed populations of WLP from Chenkan are $135 \mathrm{~km}$ away in Palizada, and $85 \mathrm{~km}$ from Calakmul. There is not enough information to allow us to say whether there are populations between these 2 areas and Chenkan; it is possible that the Chenkan WLP population is isolated.

The records obtained to date do not allow us to know whether the photographs are of a single group of WLPs or whether there are several groups. WLP groups have home ranges of 38-98 km² in Campeche (Reyna-Hurtado et al. 2009), so the distance between the cameras that photographed WLPs $(3.7 \mathrm{~km})$ makes it impossible to assert that these animals belong to different groups. In Calakuml, WLPs live in groups of 20-31 individuals (Reyna-Hurtado et al. 2009). Our photographic evidence shows that in Chenkan there is at least one group of 5 animals. Given the presence of offspring, this group is likely made up of males and females.

We only obtained photographs of WLP during the second year of the study, and although we obtained 18 photographs, these only represent 3 events in 1545 camera-trap days (645 during 2011 and 900 in 2012). Thus, the abundance of WLPs in the area is very low, or the animals we photographed have very large home ranges and do not visit the same places every year (as happens in the Calakmul region; Reyna-Hurtado et al. 2009). The Chenkan camera traps photographed subsistence hunters on multiple occasions, so it is very likely that the WLP population is under hunting pressure.

There are significant gaps in information about the distribution of mammals in the state of Campeche (Guzmán-Soriano et al. 2013), so it is possible that new records of the WLP will be obtained in the future in areas where the species is thought to be extinct. HidalgoMihart and Contreras-Moreno (2012) mention the possibility of WLP populations inhabiting the wetlands and flood forests in the region of the Terminos Lagoon. It is important to conduct more studies to detect the presence of the species in these areas, as such efforts would establish with certainty whether the Chenkan population is truly isolated. Similarly, surveys are necessary in other parts of the coastal region of the Yucatan Peninsula, particularly in wetland habitat, given that the 
recent rediscovery of a WLP population in wetlands in Palizada (Hidalgo-Mihart and Contreras-Moreno 2012), Chenkan, and Dzilam de Bravo in Yucatan State (C. Alcerreca personal communication) suggests that other populations might be found in these areas in the future.

Rediscovery of the WLP in Chenkan confers great importance on this region for the conservation of endangered species and also increases the need to establish mechanisms for WLP conservation. In Mexico, the Chenkan region is currently considered a Priority Land Area (Área Terrestre Prioritaria) and a Priority Mangrove Area (Área de Manglares Prioritaria), and the beach is listed as a RAMSAR site. Additionally, the region is considered one of the most important links connecting the population of jaguars at Terminos Lagoon with the population at Calakmul (Rabinowitz and Zeller 2010, Hidalgo-Mihart et al. 2012). Even so, the region is subjected to strong anthropogenic pressure resulting from expansion of agricultural activities (SotoGalera et al. 2010) and excessive subsistence hunting. Along with these pressures, highimpact tourist facilities have been built in the region, some of them $<5 \mathrm{~km}$ from the site where the WLPs were recorded. The apparent low abundance of WLPs in the Chenkan region, the possibility that this population is isolated from others in the region, and the pressure resulting from agriculture, tourism, and hunting indicate that the Chenkan population is at high risk of extirpation in the short term if the current conditions persist. Thus, it is urgent to implement conservation measures, including increased protection of the Chenkan region, incentives for environmentally friendly industry, and establishment of a payment system for environmental services.

This study was supported by the Comision Nacional de Áreas Naturales Protegidas, Área de Protección de Flora y Fauna Silvestre, Laguna de Terminos for project PROMOBI 2011 and 2012 "Monitoring Jaguar (Panthera onca) in the Términos Lagoon Corridor-Calakmul, with emphasis on the Priority Region for Conservation in Chenkan, state of Campeche." We are grateful to the authorities and inhabitants of the Ejido San Pablo Pixtún and Ley Federal de la Reforma Agraria for allowing us to carry out this study on their land. We thank the División Académica de Ciencias Biológicas of the Universidad Juárez Autónoma de Tabasco (DACBiol-UJAT) for logistical support.

\section{Literature Cited}

Altrichter, M., A. Taber, H. Beck, R. Reyna-Hurtado, L. Lizarraga, A. Keuroghlian, and E.W. SanderSON. 2012. Range-wide declines of a key Neotropical ecosystem architect, the near threatened whitelipped peccary Tayassu pecari. Oryx 46:87-98.

Arriaga, L., J.M. Espinoza, C. Aguilar, E. Martínez, L. Gómez, AND E. LOA, COORDinators. 2000. Regiones terrestres prioritarias de México. Comisión Nacional para el Conocimiento y uso de la Biodiversidad, México. Available from: http://www.conabio.gob.mx/ conocimiento/regionalizacion/doctos/Tacerca.html

COMisión NACIONAL PARA EL CONOCIMIENTO Y USO DE LA Biodiversidad. 2009. Manglares de México: Extensión y distribución. 2nd edition. Comisión Nacional para el Conocimiento y Uso de la Biodiversidad, Distrito Federal, México.

Guzmán-Soriano, D., J.A. Vargas-Contreras, J.D. Cú-Vizcarra, G. Escalona Segura, O.G. RetanaGuiascón, A. González-Christen, J.A. BenítezTorres, J. Arroyo-Cabrales, J.C. Puc-Cabrera, AND E. Victoria-Chán. 2013. Registros notables de mamíferos para Campeche, México. Acta Zoológica Mexicana (nueva serie) 29:269-286.

Hall, E.R. 1981. The mammals of North America. Volume 2. John Wiley \& Sons, New York, NY.

Hidalgo-Mihart, M.G., and F.M. Contreras-Moreno. 2012. Registro de pecarí de labios blancos (Tayassu pecari) en la región de la laguna de Términos, Campeche, México. Revista Mexicana de Biodiversidad 83:868-887.

Hidalgo-Mihart, M.G., F. Contreras-Moreno, and L.A. Pérez-Solano. 2012. Jaguares de los humedales del sureste de México. CONABIO. Biodiversitas 104:6-11.

Keuroghlian, A., A. Desbiez, R. Reyna-Hurtado, M. Altrichter, H. Beck, A. Taber, and J.M.V. Fragoso. 2013. Tayassu pecari. In: IUCN, compiler, IUCN Red List of Threatened Species. Version 2013.2. [Accessed 27 February 2014]. Available from: http://www.iucnredlist.org

LÓPEZ-MendozA, R. 1995. Tipos de vegetación y su distribución en el estado de Tabasco y norte de Chiapas. Universidad Autónoma de Chapingo, Chapingo, México.

March, I.J. 2005. Pecarí de labios blancos. Tayassu pecari (Link, 1795). Pages 522-524 in G. Ceballos and G. Oliva, coordinators, Los mamíferos silvestres de México. Fondo de Cultura Económica and Comisión Nacional para el Conocimiento y Uso de la Biodiversidad, Distrito Federal, México.

Norma Oficial Mexicana NOM-059-SEMARNAT-2010. 2010. Protección ambiental-especies nativas de México de flora y fauna silvestres-categorías de riesgo y especificaciones para su inclusión, exclusión o cambio-lista de especies en riesgo. Diario Oficial de la Federación. 30 December 2010. Distrito Federal, México.

Rabinowitz, A., and K.A. Zeller. 2010. A range-wide model of landscape connectivity and conservation 
for the jaguar, Panthera onca. Biological Conservation 143:939-945.

Reyna-Hurtado, R., E. Rojas-Flores, and G.W. Tanner. 2009. Home range and habitat preferences of white-lipped peccaries (Tayassu pecari) in Calakmul, Campeche, Mexico. Journal of Mammalogy 90: 1199-1209.

Soto-Galera, E., J. Piera, And P. LóPez. 2010. Spatial and temporal land cover changes in Terminos Lagoon
Reserve, Mexico. Revista de Biología Tropical 58: $565-575$.

SowLS, L.K. 1997. Javelinas and other peccaries. Their biology, management, and use. 2nd edition. Texas A\&M University Press, College Station, TX.

Received 28 February 2014 Accepted 18 September 2014 